\title{
Concept of family among Kyrgyz and Native American tribes
}

\author{
Saltanat Mambaeva \\ Kyrgyz Turkish Manas University, Bishkek, Kyrgyzstan, Turkey. \\ Received 4 July, 2012; Accepted 8 April, 2014
}

\begin{abstract}
The growth of technology in the world is the highest achievement of present-day civilization, but it is bringing us into a type of life and unifying our style of living, clothes, behavior and even language. Technology has replaced live communication, and this seems to be marring the borderline between diverse cultures as people become more and more technologically dependent. Smaller nations in this globalized world are gradually losing their cultures and languages, their unique inherited family values, which have been with them through many centuries and through the countless experiences of hundreds of generations. The family, once a source for each family member, has become only a tick on the documents, and it does not play the same role as it did before. Nevertheless, there are a few groups who try to keep their close family relationships and their own family concept for the next generation. Living in large extended families, they show that the family really is a small community, but from the family begins the society and the state. In this article I will refer to some family values of native American tribal peoples and Nomadic Kyrgyz tribal peoples from Central Asia. These two divergent groups have much more common between them and there is much to be shared.
\end{abstract}

Key Words: Family concept, Native American tribes, Kyrgyz, customs and traditions

\section{INTRODUCTION}

In this article I will try to show some results of my research and my observation, which include the concept of the family of two quite diverse people's living in different parts of the world but keeping very similar customs and traditions in their families, clans and tribes. They are the Kyrgyz nomadic tribal from Central Asia and the indigenous Native American tribal peoples. At a time when population of big cities is taking away the traditions and cultures of many nations and nationalities, and at a time when people are lost in the web net, internet and other bio-technological achievements, achievements which surely improve the search for information but damage the real values of alive communication, people are obtaining information not from simple ordinary books but the different media; and being involved in all this, people have forgotten about the other more valuable and real values such as the family, family relationships, family customs and traditions, family culture and cultural values. The loss of real family values has resulted to a huge gap between us, our parents, grandparents and memory

\section{E-mail: sa Ita na tma mba eva @gma il.com}

Author a gree that this article rema in permanently open access under the terms of the Creative Commons Attribution Lic ense 4.0 Intemational Lic ense 
about ancestors.

According to Kyrgyz folklore and customs researcher (Akmataliev and Акматалиев 2002), the Russian historian (Bartold and Бартольд, 1997), our ancestors cared about the future of their generation, they cared about keeping their understanding of the family, tribal, kinship and family values, and they tried to bring us the things which have now developed into huge techno values. The tribal peoples living in Eurasia and Central Asia are not considered as indigenous people of the North America, Russian Siberia or African continent and Australia, but ethno-national groups and nationalities.

The tribal systems of these peoples were studied, but these peoples were mostly grouped into one or more groups, maintaining following relationships as kinship and tribal relationship. For example, Kyrgyz tribal life was studied as part of a group Eurasian tribes and they were considered to have one and the same type of relationship in families, tribes and nations. At the end of the $20^{\text {th }}$ century and the start of the $21^{\text {st }}$ century appeared a few works devoted to Kyrgyz tribes by Oliver Roy, Gregory Gleason, Y. Gumilev and Kyrgyz scholars, which were quite interesting and new information about Kyrgyz tribes and their historical background. In the 19th century and beginning of the 20th century the next scholars such as: (Valihanov, 1985), (Abramzon, 1971) and (Zuev, 2004) had investigated the tribal Kyrgyz people and came to the idea that Kyrgyz tribes are one of the most ancient tribes of Inner Asian region and nowadays Central Asia.

When I started my research, I was concerned with the transformation of family values in my own culture and among the Kyrgyz people. This required me to explore our Kyrgyz traditional cultural values and compare them with the other Eurasian and Central Asian nomadic peoples, particularly the Kazakhs, Mongols and other peoples from the Siberian part of Russia. At the very beginning of my research I have found out that the Kyrgyz tribal concept of family clan is connected with its gender roles; child rearing; the sharing of wealth, government and nature which are all quite different from the other people living side by side with the Kyrgyz, such as Kazakhs, Uyghur and Uzbeks. Even Kazakh people who is the closest (according to their come traditions, and being nomads) to Kyrgyz, but they were mostly steppe nomads, and their customs and traditions in a way have got a lot of differences from the Kyrgyz. And I put forward the following question:

Are there any other cultures and peoples in the world (because of Turkic speaking tribal people, such as Kazakhs and tribal people of Siberia) who have the same values as Kyrgyz people, the same family concepts, similar customs and traditions?

As I can use English, I found the following quote in one of the sources about tribal life of the American Indians: "For all the diversity of the first Americans, they inherited certain common traits from their Old World ancestors. Reflecting their Asiatic heritage, they were generally of short and medium stature, with straight black hair, light brown skin and prominent cheekbones - features. 1492 reinforced Columbus's mistaken conviction that he had reached the East Indies and prompted him to assign to the inhabitants the inaccurate yet enduring title of Indians". (The First Americans. Time Life Books, 1992)

It was like a push for me, why not compare two different and, quite far apart cultures? The other thing which was really interesting for me was language. Could the hunters who had crossed over the bering straits keep even a tiny part of their ancestral language? Some American scholars try to deny this (for example, Vine Deloria: "Scientists, (and I use this word loosely) are committed to the view that Indians migrated to this country over an imaginary Bering Straits bridge, which comes and goes at the convenience of the scholar requiring it to complete his or her theory. Initially, at least, Indians are (said to be) homogenous. But there are also eight major language families within the western Hemisphere, indicating to some scholars that if Indians followed the trend the migration went from the east to west; tourists along the bering straits were going to Asia, not migrating from it" (Vine, 1995). May be Vine Deloria was right in his own way.

The second point is the emergence of people who are quite similar in appearance to our people, also the relation of the Kyrgyz and Native Americans to nature, to women, to domestic animals and their customs and traditions. Kyrgyz people, as they were nomads they moved from Enisey River in Siberia to the south, in search of more safe and warmer place according to Butanayev and Butaneva's research of the early Kyrgyz people's history and folklore (Butanayev et al., 2002). Kyrgyz people have got a lot of common customs and traditions with Siberian peoples as Khakas, Tiva, Buryuat and many others who are still living in the Siberian regions of Russia.

On the basis of the bering bridge theory "The resourceful Asian nomads who made this pioneering trek to America ages before European explorers dreamed of its existence never paused to savor their accomplishments", "...among the people who ranged into Siberia during the late stages of the Ice Age were nomads from what is now northern China..."(that is, modern Kyrgyz tribes, Khakas Tivas etc)... These well prepared hunters may have been the immediate antecedents of the American Indians (The first Americans, 1992). Perhaps I am idealizing the culture of tribal peoples, but in comparison with the western cultures which conceptualize they are quite different from Kyrgyz (for example, the concept of the nuclear family, male domination (among the English, Spanish and others and mostly among Islamic countries), breaking the will of the child, authoritarian government, and the most dangerous thing for me was the belief that nature was created for the benefit of humans. 
As Kyrgyz people lived in their own world before the Russian empire brought the "civilized world to them", the same has lived the American Indians before the arrival of the Europeans onto the American continent.

\section{Understanding family concept}

Everyone has their own conceptualization of their own family and at the same time they believe that they know what family is. Therefore, when teaching about family matters, it is essential to be aware of the apparent contradiction between personal perspectives and "scientific knowledge" (Levin and Jan, 1992). The concept of family differs for family. And modern people sometimes fully lost the value of the family and family concept: gay families; lesbian families; families who do not want children, because they want to live and earn only for themselves; families where animals are considered as a member of the family, and it would be worshiped more than a human being; families where children forget their parents and do not contact them throughout their whole life; families where children are sold for money; and increasing number of divorced and one parent families. All these types of family are quite strange for people living in clans and tribes.

For example, Kyrgyz people, they are still keeping their ancestral type of family: grandparents, father, mother and children. And each family should have at least one child to inherit the family line in the clan. The concept of family has been widely investigated by American and western European scholars of anthropology and sociology, as for Kyrgyz scholars they just get involved into the bulk of theories about family and family concept.

Family is a network of relationships between the members of one family, but in the extended families, it would be difficult to understand where the exact family is, as people living in and nearby. All these people would be included in the family tree. What conceptualizations can be labeled as family by the individual? How do people define their family, are mature enough to know each member of the family and have their own conceptualization of family? (Gilby and Pederson, 1982). Individuals could have a variety of conceptualizations of family, for example, one for their own family of today, one for their own family in the near past, one for their family in the more distant past. We can also have a variety of more or less different perspectives of family generally. The individual's identity can be strongly connected to the perception of family membership.

Murdock as an anthropologist defined the "nuclear family" as classifying societies based upon the sole nuclear family or combinations of these units to form polygamous and extended families. It is essential to challenge the concept of family (Murdock, 1949). At the same time it is equally important to distinguish what family is, for Asian nomads and western people. For
Asian nomads as Kyrgyz people are: family is the most important, most people in the world define their family their future, the role of himself/herself in that family, the contribution of himself/herself into the growth of their family clan etc. And, of course, inheritance of the family values: customs, traditions and continuation of the family tree via children. (If the Kyrgyz family could not have a child, they usually adopt their relative's child, or just adopt from the family who would agree to give their child for adoption).

\section{Kyrgyz family and clan}

Scholars studying clans and tribes have observed multiple types of families existing within a society. One type is ethno-nationality - the common cultural and linguistic traits and shared history or heritage. During Soviet times the nationalities policy specifically linked ethnics to politically recognized and territorially defined groups. Religious identity, a second face of culture, is an ideological or civilization identity based on doctrinal affiliation.

Family of tribal people such as Kyrgyz is sacred - they value all information about their family and clan relationship, and their family history. The family is the reality; the society is changeable as is the policy and the state. For most tribal people the new type of family is quite tough to accept, the nuclear family is nothing. Ethno-national and religious identity have been highlighted as a causal variable in the protracted conflicts of the last decade in the former Soviet Union and Eastern Europe. However, it has not led to conflict in post-Soviet Central Asia. To explain its absence, it is necessary to focus on the clan as the critical unit of analysis in Central Asia. Studies of conflict and transition have ignored the clan (Collins, 2006).

Kyrgyz people got used to living in clans - a word which was usually not mentioned and omitted when identifying Central Asian peoples and which only appeared after World War 2 (WWII). Most of the works about tribal and clan structures which were done by Soviet -Russian ethnographers and western scholars were not widely discussed and published on the territory of the former Soviet Union and there were no local ethnographers who would be involved into the mentioned researches of Central Asian tribes and clans. After the collapse of the union of soviet socialist republics (USSR) some works were translated into Kyrgyz language, as the works by Butanayev, Bartold and others, and only now Kyrgyz people have much more free access to the works of the western and other European ethnographers.

Clan identity is a face of culture in many semi-modern societies in Asia, Africa and the Middle East. The clan is a unit of analysis addressed by neither contrastive nor international relations hypotheses on identity and conflict.

Clans have often been entirely ignored or dismissed as 
primordial and sub national units. However, the clan can be approached conceptually and theoretically as a collective identity network.

Measuring identity, especially collective identity, is a challenge. Clans are informal social organizations in which kinship or "fictive" kinship is the core, a unifying bond among group members. Kinship is necessary even for modern people in the process of communication, as it is an inseparable belonging among tribal people as Kyrgyz, they should know according to their belonging to that or another tribe, clan and kinship until the seventh generations back (Among American Iroquois group of tribes, it is necessary to foreseen the future seven generations, as keeping the pastures, lands, customs etc). Clans are identity networks consisting of an extensive web of horizontal and vertical kin-based relations. Clans are rooted in a culture of kin-based norms and trust, but also serve rational purposes. A clan is an organized group of people distinguished by a single blood family and including all siblings.

The clan is an informal identity network based on kinship ties and is common in semi-modern societies. In such societies, identities embedded in informal networks such as clans are stronger than formally institutionalized ethno-national and religious identities. The Kyrgyz family revolved around one type of relationship - patrilineal, meaning kinship was determined along male line. Tribes - uruu - are associations of clans - tykym. The Kyrgyz now have more than 40 well-known tribes, including Solto, Sayak, Kushchy (eagle), Bugu, Bory(Wolf), Mongy (hill), Sarybagysh, Nakay - names of tribes of different origin, but there are many animal and birds names.

The role of women in the Kyrgyz family is high and honorable, and it is not limited only by keeping the women as an oven of the family, and as the babygiver, but also as the keeper of family tree also, and as the person who gives the elementary knowledge to children at home about their family, clan, tribe, and the older women were the oral keepers of the seven generations family tree and she gives her knowledge to the next most reliable and honorable woman of the family. The elderly, wise woman who is still worshipped Umaiene - Buguene - is the mother of our nation (As clan mother among American Indians). The tribes practiced a primitive way of householding; now times have changed but the role of woman in the family did not change in the mentality of modern Kyrgyz people.

For example, Kyrgyz proverbs about women can say more about the place of a woman in the family (all translations done by the author of the article Mambaeva S):

1. Kizdin kirk chachyuluu - The 40 braids of a girl is more honorable

2. Atalashtan alto bolgoncho, eneleshten ekoo bolsunThan have six people according your fathers' line it is better to have only two close relatives according to your mother's line.

3. Kizi bar yi- kyialdyy yi -The house with a daughter is a dream house.

4. Jakshi katyn jarym yrys - The good wife is already a good fortune given to you.

5. Tyrmyshtyn tytkasi ayal-The woman is a Core of a life.

A Kyrgyz wedding was mostly an arranged wedding, but it was seldom against the will of the daughter. There is a very interesting and beautiful ceremony of putting earrings onto the future bride's ears; this is actually the engagement ceremony. The boy who liked the girl should put the earring to his future bride's ears, going to her house accompanied by his sisters-in-law, and on that day the two families would settle the date of the wedding. All these type of ceremonies are still kept among Kyrgyz people, even some American volunteers of Peace Co in Kyrgyzstan were trying to break it via telling about another who is not Kyrgyz, but which was widely spread during the Soviet period especially-kidnapping of a bride. The last one start to exist among Kyrgyz people mostly after Socialistic revolution as all tribes should be equal, the poorer clan and tribe members were kidnapping the daughters of richer clans to "balance" the equal rights, with the help of and under the cover of raskulachivanie (when the belongings of the rich families was shared among the poor).

Of course, among the Kyrgyz tribes before the Russian came, Muslim missionaries tried to suppress the role of leading women, but anyway, in larger Kyrgyz tribes the role of women is still very high. And child rearing is quite different from westerner practices. For example, the Kyrgyz very seldom oppose the will of their children; and if this is connected with the adult, the tribal elders usually solve the problem of whether to allow the wish of the man or the woman to be take precedence. If a child is being raised by a single parent (in a case when there is only mother), usually the mother's male-relatives from the clan help with brining up the young man and teach him male skills of domestic household.

So the Kyrgyz trust women more than men, especially in child rearing. In the case of the Native Americans, the Europeans were greatly surprised by the role of the father - "the (clan) system takes from the father his proper place as the head of his family and leaves him comparatively little control of his children. Christianity had to contend with that, and is gradually overcoming it" (Collins, 2006). As for the Kyrgyz family clan, it is a supportive system which worked and still works among modern Kyrgyz families too.

As far the Kyrgyz, the family is considered a patrilineal relationship; the boy in the family since childhood should learn all about his seven grandparents, in other for him to be able to answer questions when asked by others about his belonging to the clan and tribe. And in case he forgets or did not know any of his grandparents, this is equal to losing face to his family clan who did not teach him. But 
the family history is better told and known by women of the family. The woman should remember all the details about her own and husband's family tree as she should teach her children about their grandparents.

The role of a good storyteller among the Kyrgyz people is given to the grandmother, but the teller of the tribal history is given to a grandfather. And if the grandfather was a manaschi - an oral teller of the epic Manas about the Kyrgyz national hero - the women would not interfere.

\section{The Native American family concept}

Indian life revolved around two types of relationships: patrilineal and matrilineal. In a patrilineal relationship, kinship was determined based on the male line, while in the matrilineal kinship was determined based on the female line. In a matrilineal society the role female influence was greater, the residence was matrilocal, and the women owned the lodge, the farms or gardens, and they also had a role in tribal affairs. Indian women had great individual freedom in most tribes; they were even portrayed as being downtrodden and hardworking "slaves" to Indian men. And women had autonomy within the home, and they had the right to vote and wield influence in both family and tribal decisions (Moulton Candy, 2001). And women alone determined when they would have children. But in most cases Indian women were not forced to marry against their will, although families arranged marriages.

1. A number of other relationships existed as well:

2. Polyandry-a woman has more than one husband;

3. Polygyny- a man has more than one wife;

4. Levirate - situation where the place of a dead husband is immediately assumed by his brother;

5 . Sororate- situation when the place of a dead wife is immediately assumed by his sister[17].

The last three types of relationships also existed among Kyrgyz tribes, but the levirate and sororate relationships are less common nowadays.

\section{The global world and its impact on tribal relationships}

The last two decades, an epoch of globalization have brought many changes into the lives of different small nations, nationalities, ethnic groups and to a lot of smaller groups of indigenous people living in different parts of the world. Becoming civilized, people started to lose not only family values, which were kept by their ancestors for thousands and thousands of years from one generation to another, but they started to lose their language, uniqueness, their own customs and traditions, and of course their mentality. Instead of their traditional ways of communication, most of the people now prefer cyber- communication, which forces them to forget their ethnic backgrounds, their language, their national and traditional values and roots in each culture.

In acquiring the possibility to learn more and get more from the globalizing life, people started to ignore their family tree, which is considered as the vestiges of olden time, which is easy to find with the help of the world, where some web people will try to find your ethnic origin, your family tree via the Internet and family tree websites, for a definite sum of money. Small countries and states are striving in this globalized world, even with the lack of financial support to develop their own language and share it with the whole world. Most of these small countries have their own historical backgrounds which is so long and diverse, and full of different worthwhile historical events.

This type of countries belongs to the Kyrgyz Republic or Kyrgyzstan, as people now name it, which appeared as an Independent state only 20 years ago. This is the smallest country in the center of Central Asia with a population around 5.2 million people. The Soviet Union was a "good supervisor" for such a small country and nationality as the Kyrgyz were at the beginning of the XX century. All the resources were used, only for the development of the Soviet image and industry; as for the local people, they were not allowed to take part in all those changes. It could be seen in the policy of Stalin who had genocide all intelligentsia and well educated people even from poor families, being scared to be killed or not promote most of the scholars, political leaders of the $40^{\text {th }}$ till $80^{\text {th }}$ of the $21^{\text {st }}$ century married Russian women, to know better Russian language and to be promoted according to the communist party of the soviet union (CPSU) policy of that time. And now the echo of that political interfere into family structure as we can see in the generation who was born in the 60-s and 70s who are highly russified and they do not even follow elementary Kyrgyz traditional ceremonies in the families because they do not know, as it was forbidden (those are mostly from the capital of Kyrgyzstan nowadays Bishkek(former Frunze)). Only after the 90s and collapse of the USSR, people started to return to their roots and start to learn and study their historical background and to try to use some of the forgotten customs and traditions.

Surely the last period has brought a lot of new changes into the social life of the Kyrgyz people: for example, education, and economy and into agriculture. But the Kyrgyz people paid for it by their national values, customs, traditions, religions and family values. The people were discriminated against not according to their race, or their color of skin, but their language and culture. The Kyrgyz language (which is belonging to Turkic group of languages) was less taught at schools before, especially in the capital and regional centers, that was the reason that $90 \%$ of schools were of the Russian language schools. In the culture of tribal Kyrgyz people have been kept more from Tengrianism and Shamanism, than from 
Islam.

\section{Kyrgyz customs and traditions}

The culture of Kyrgyz people was at a risk to be lost during the last two centuries, during Tsarist Russia and then during the Soviet period, because cultural rituals and other customs and traditions were forbidden, as there were lots of religious staff in the Kyrgyz culture. For example, the wedding ceremony at present time is being done mostly in the western way: bride in a white gown and the groom is in the westernized suit.

Kyrgyz people had to forget about their customary engagement ceremony and wedding games on the horses, with the participation of whole villages and even the whole tribe - traditions they had inherited from their ancestors. It was forbidden as it gathered a lot of people together and this was considered dangerous for the ruling power (especially during the Soviet times). Young people were gradually persuaded psychologically that their customs and traditions were becoming old fashioned, and they therefore did not place the same values on them as their grandparents did, and they had to adapt them to modern life as the whole western world did.

Surely this has brought so many changes into the mentality of Kyrgyz people and the values of national traditions that young people started to hate their own customary wedding ceremony; instead they aimed towards a Soviet type of wedding with an exchange of two rings, with a lot of vodka on the table, dancing of drunk young and old people together and the white wedding gown, instead of the national bridal costumes and bridal jewelries. The big city customs connected with wedding is quite different from the traditional village customs, but the last decade there is no big difference between the rural weddings and urban, as people who has got some money usually celebrate the wedding party in rich restaurants of Bishkek.

The Kyrgyz people have beautiful wedding ceremony which is being revived at the present time, and this is good for us. It consists of the bridal party in the house of a bride, her departure from home - kizuzatyy, which consists of different games among the girls and bridal friends and relatives. There are alot of songs kizuzatyykoshok, which are being sung by close aunts of the bride and relatives. These songs are not ordinary; they are devoted only to the bride who is going to marry. These songs talk about her parents, about her characteristic features, about her achievements, her best skills etc., they are like a limericks, as they are told in an oral way and only once, but very positive.

In preparing her dowry all female relatives of the bride sow about 40 blankets, about the same number of soft woolen and patch worked mats for sitting, pillows, curtains, woolen floor and wall embroidered carpets, and different type of clothes (embroidered hats and jackets, national embroidered skirts for everyday use, gowns etc). This is also a very awesome ceremony, when female relatives bring their gifts and present them to the bride; and they have to bring gifts for her fiancé too, as he is becomes from the day of their engagement also a relative to the countless bride's relatives. Time has changed even the people's relation to all their national customs and traditions. The naming of children, for example, has lost its value, as most of modern people prefer more short and westernized names instead of traditional names of Kyrgyz people. The name giving ceremony also consists of a lot of interesting things, which play a great role in the life of the new born child: the name is like a face for the future member of the society. There are names which are given according to a person's belonging to this or that tribe. From one's name, people could guess about the position of a person or his status in the tribe. But the present day has changed all this and people give different names and do not think about the future of their child.

As a result of the century of oppression, the Kyrgyz may have become more civilized, but they also the lost the values of their ancestors which previous generations were trying to keep for the present generation.

\section{Kyrgyz Language}

The Kyrgyz language at present time is reviving from loss as are many languages all around the world. Most of the vocabulary in the speech of the modern people consists of a mixture of Kyrgyz words with Russian and even English. At the same time we can see the influence of Turkish culture and mentality on our young people's effort to get an education. (There have appeared about 20 specialized Turkish private schools during the last 20 years and 4 universities and colleges around Kyrgyzstan), and also the influence of the Arabic and Turkish.

Modern language purists try to cleanse the Kyrgyz language, and try to use original Kyrgyz words on television and other mass media, but the modern people are deaf to these acts. They have started to be more cyber oriented, and instead of Russian they have now started to use more foreign words. They have started to learn more languages in order to get better education abroad, and this has brought new problems for the survival of the language and culture. People are leaving their own country in search of a better place for living and working, and of course earning. And they are right from their point of view, but how much does it cost? I mean psychologically, financially, socially and according to the moral side. It is not so easy to be a foreigner in any country even if you know the language and have learned the history and laws of that country to which you came.

The Kyrgyz people, having a nomadic type of culture, are quite adaptable and adjustable to any new environment, and they have good language learning skills, but all these skills can interfere in the preservation of their own 
culture and traditions. The next generation may very well have only technical skills, the skill to use multilingual speech, but will have no common ties with their own people, culture and language. This is quite tragic for any nation with such a huge historical background as the Kyrgyz people have. The elderly generation is even fighting to keep all those values which came to us from our grandparents, but it is not enough. Some new action needs to be done for saving all those cultural values of the small nationalities such as the Kyrgyz and others who has been living through these kinds of problems. And maybe some global actions need to be done by small nations, ethnic groups to save their real values.

The indigenous peoples of the United States (US), the Native Americans have also undergone and are undergoing similar if not larger tribulations. Their tribes and tribal chiefs have done a great deal to revive their traditions for the sake of preserving their long and interesting culture and their languages that are largely unknown to the world. Going deeper into the history of the Native American people, I also see this as a mirror of our own history. Native American tribes were living on the land of the present-day US and Canada for thousands and thousands of years; they kept their own history, statehood, their languages, their traditional way of living in tribes. But look at them now; they have lost their languages as well as their culture and values also as my people did as well. And people are starting to realize this real loss resulting from globalization and other interferences into the lives of small nations, ethnic groups and nationalities. And it is almost too late to revive all the things which they have acquired before.

Where is the way out? What should be done to help all these people to keep the values they have left? I think steps to keep all their values have already started. We only have to pay more attention and try to help them as much as we can. On a governmental level efforts should be made to keep maintaining the cultural values of each nation and nationality. Scholars who are already doing a lot to revive all these nations and nationalities should be supported both by society and by state governments.

When people lose their uniqueness, they are lost people, and there is no way back. People who are already globalized are suffering from this; they have started to understand that nature gives much more than the technological world can give. Nature gives them more energy than all these technical advances used nowadays, such as the Internet, television and other mass media through which people communicate at the present time in order to communicate live. And I really appreciate the work of Green Peace, the anti-global movement, and other types of such organizations that have realized changes of the world and try to save it. I can easily understand my parents and the elderly people in my country when they are asking us to come personally and not speak by phone or via Internet. Nothing is as valuable as live communication with people who have so much to tell us about their customs, traditions, or even just to talk and tell their life stories. But we often don't have time to listen to them; we are all in a rush, and we try to economize our time when talking with them. But they are leaving us, they may be the last people who really know the valuable information from the history of our tribe and nation or just some stories connected with the building of our country and with the writing of the history of our people.

The idea of writing this article came when I heard one of the tribal women from the US telling us how she envied us Kyrgyz people in having their own country and their own language. As for Amerindians, it is sad that their tribes have lost their languages. They may know some vocabulary inherited from their parents and grandparents, and there may be only about 20 people speaking their language but they are getting old so the tribes and must to take from them as much as they can. This kind of situation is not only among the tribes living in the US but with most ethnic groups, nations and nationalities living all around the world.

Of course many scholars and researchers have talked a lot about the points that were explored in this article, but the idea of this article is to get people in this era of globalization to pay attention to the vanishing peoples, to their unique culture and languages which can easily disappear and we can never learn from them anything more, but to just be careful and let them continue to exist in this multi-colored world.

\section{Conflict of Interests}

The author(s) have not declared any conflict of interests.

\section{REFERENCES}

Abramzon SM (1971). Kirgizes and their ethno-genetical historical and cultural connections, Moscow, p. 361. ISBN 5-655-00518-2

Akmataliev A, Акматалиев AC (2002). Каада-салт, үрп-адат, адамдык оң-терс сапат. - Бишкек: Бийиктик, - 400 бет. - ISBN 9967-21-100-8.

Bartold VV, Бартольд BB (1997). Кыргыз жана Кыргызстан тарыхы боюнча тандалма эмгектер / Түз. кошумча түшүндүрмөлөр ж-а алгы сөз жазган Ө.Караев; Кырг. котор. котормочулар жамааты; Кыргызча чыгарылышынын илимий редактору - филология илимдеринин кандидаты С. Кайыпов. - Бишкек: «Айбек» фирмасы. - 456 б. - ISBN 9967-12-002-9.

Butanayev V, Butaneyeva I, Ene sai K (2002). Folklore and history. Bishkek., (translated from Russian by/ O.Karateyev) (Бутанаев B, Бутанаева И (2002). Эне сай кыргыздары: фольклор жана тарых. (Кот.Каратаев.О). Б.: Кыргызстан-Сорос Фонду,)

Collins K (2006). Clan Politics and Regime Transition in Central Asia, University of Notre Dame, Indiana ISBN: $9780521839501 .$, April.

Gilby RL, Pederson DR (1982). The development of the child's concept of the family. Can. J. Behav. Sci. 14:110-121.

Levin I, Jan T (1992). Understanding the Concept of Family., Family Relations, Published by: National Council on Family Relations Stable, 41(3):348-351.

http://www.jstor.org/discover/10.2307/585202?uid=2134\&uid=2\&uid= 70\&uid $=4 \&$ sid $=21103874691371$

Moulton C (2001). Everyday Life Among the American Indians: 1800 to 1900 (Writer's Guide to Everyday Life Series)F@W Publications 
http://www.abebooks.com/Everyday-Life-Among-American-Indians1800/12126295757/bd

Murdock GP (1949). Social Structure. New York: The MacMillan Company. https://archive.org/details/socialstructure00murd

The First Americans. Time Life Books (1992). Editor: Thomas H. Flaherty. Library of Congress cataloging in Publication Data, Washington DC. VA. http://www.amazon.com/Time-Life-LibraryCurious-Unusual-Volumes/dp/B000E6JKT2

Vine D Jr (1995). Red Earth, White Lies: Native Americans and the Myth of Scientific Fact, New York: Scribner. http://www.jstor.org/discover/10.2307/20739402?uid=2134\&uid=2\&ui $\mathrm{d}=70 \&$ uid $=4 \&$ sid $=21103874691371$

\section{Citations}

Valihanov CH (1985). Ch. Works in 5, Alma-Ata, 2:48.

Zuev YL (2004). The strongest tribe, Almaty, p. 35-46. 